rounded pieces of ice of all sizes mixed in loose ice powder. Friction produces various markings on the rolled ice.

There is altogether a remarkably small proportion of carried rock-débris mixed with the ice. The whole field of ice on the Spital Alp simply portrays a "Staub Lawine," or dust avalanche on a large scale. In the course of a few years nature itself will have removed the last signs of a wreckage which at present hundreds of willing hands are doing their best to clear away in part from road and Alp.

Maria M. Ogilvie.

\section{THE LATE PROFESSOR} HOPPE-SE YLER. ${ }^{1}$

E RNEST FELIX IMMANUEL HOPPE ${ }^{2}$ was born in Freiburg on the Umstrut (Saxony) on December 26, 1825. At the age of nine he lost his mother, and at eleven, being left an orphan by the death of his father, he was taken charge of and educated by the governing body of an endowed institution in Halle. After the completion of his school course he commenced in 1846 the study of the natural sciences as a student of the University of Halle. Migrating early in his student's career to Leipzig, he had the good fortune to lay the foundations of his knowledge of anatomy and physiology under the three distinguished brothers Weber (Ernst Heinrich, Wilhelm and Eduard), to study chemistry under Erdmann, and under the eminent physiological chemist Karl Gotthold Lehmann, medicine under Oppolzer, surgery under Günther, and pathological anatomy under Bock. Hoppe spent the last two semesters of his student's course in Berlin, following the courses of Romberg, Langenbeck and Casper. He took the degree of Ioctor of Medicine in 1850 , presenting a dissertation "De cartilaginum structura et chondrino nonnulla," which he dedicated to his former master E. H. Weber, and which indicated the impulse he had received towards anatomical as well as chemical investigation, on the one hand through the influence of the Webers, on the other through that of K. G. Lehmann.

Having settled in medical practice in Berlin, Hoppe was appointed medical officer to the workhouse, and whilst occupying this post, devoted himself to re-

searches, partly chemico-physiological and partly clinical. To the former class belong investigations on cartilage bone

1 'Though some weeks have elapsed since the death of this eminent man of science, a brief account of his life and an attempt to convey some idea of the part which he played in the advancement of physiological chemistry may not prove uninteresting to the readers of NATURE. In the preparation of this paper $I$ have been greatly assisted by the information contained in an article which appeared in the Vossiche Zeitung of August i2.-A. G.

2 The subject of this notice changed his name from Hoppe to Hoppe-Seyler somewhere about the year 1862 .

NO. 1354 , VOL. 52 ] and tooth, as well as chemical analyses of certain so-called transudations; to the latter, studies of which the object was to discover the physical principles which underlie many of the phenomena revealed by the percussion and auscultation of the chest in disease. In 1856 , Hoppe was appointed Prosector in the University of Greisswald, where he qualified as Privat-docent; here, however, he only remained until $\mathrm{I} 858$, when he was recalled to Berlin

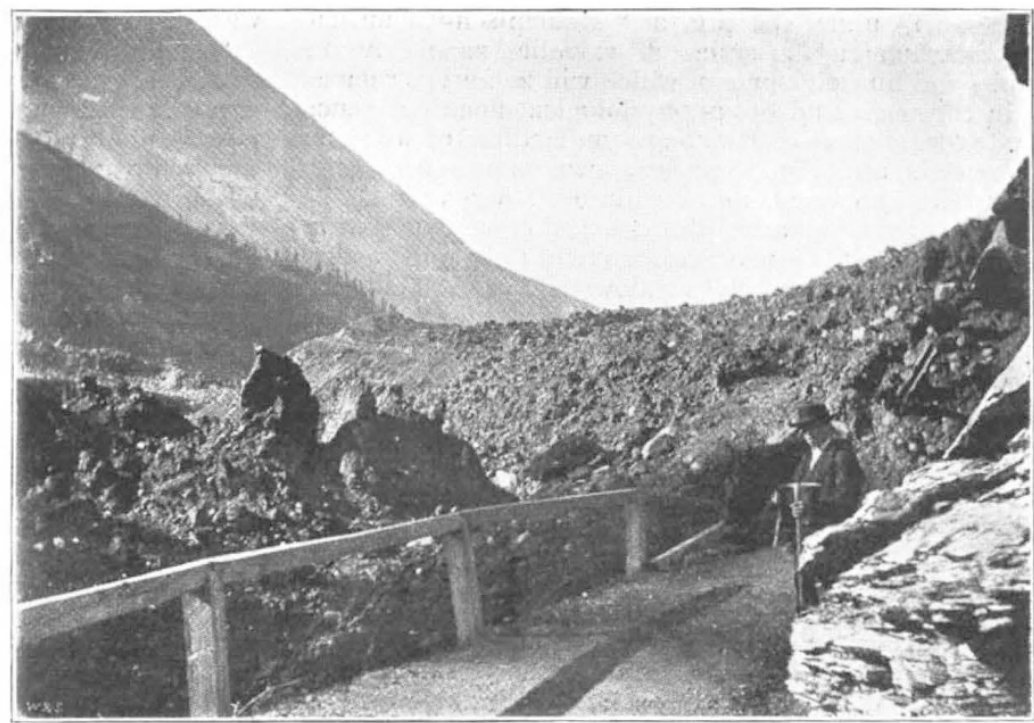

FIG. 2.--Return stream covering the Gemmi road at the Stierenbergli corner.

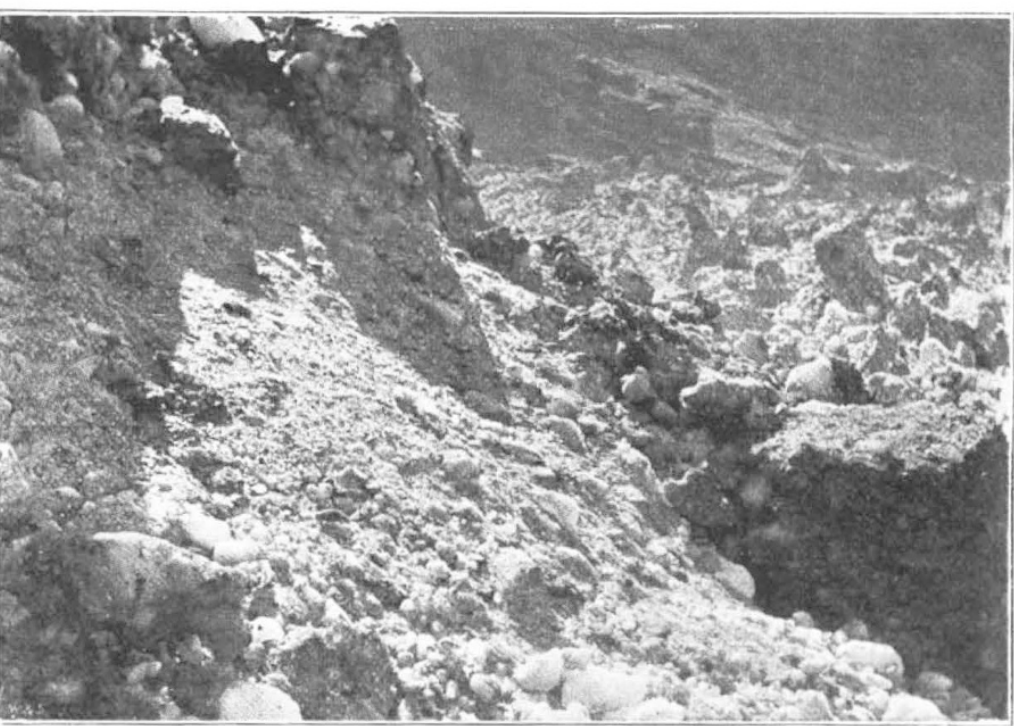

FIG. 3.-Ice structure in the avalanche.

by Virchow, in order to act as his assistant. Virchow had just been appointed the first ordinary professor $o_{f}$ pathological anatomy in the University, and Hoppe, as his only assistant, was at first called upon to take a part in all the work of the Pathological Institute, whether anatomical or chemical. Very soon, however, he was enabled to confine his attention to researches in physiological and pathological chemistry, and to the superintendence of the chemical laboratory of the Insti- 
tute. In 1860, Hoppe was appointed an extraordinary professor in the philosophical faculty of the University of Berlin. In I86I (he had now assumed the name of Hoppe-Seyler) he was appointed to the chair of Applied Chemistry in the University of Tübingen, where he had as colleagues the botanist von Mohl, the physiologist Vierordt, the anatomist Leydig, the chemist Strecker, and the great physician Niemeyer.

It was whilst in Tübingen that Hoppe-Seyler published (1866-1870), under the title of "Medicinisch-Chemische Untersuchungen," a series of valuable papers by his pupils and himself, some of which will be always referred to by thorough students of physiological chemistry; such are the researches of Diakonow on lecithin, of Miescher on nuclein, and Hoppe-Seyler's own papers on hæmoglobin, its compounds and certain of its derivatives.

When, in 1872, after the conclusion of the FrancoGerman war, the German Government gave to Strasburg the new and splendidly-endowed Kaiser Wilhelm's Universität, Hoppe-Seyler was one of the distinguished men chosen to fill its chairs, being appointed to the only ordinary professorship of Physiological Chemistry in the German empire. Among those who were called with him, and who were destined to shed a brilliant lustre on the new academy, which had arisen Phœnix-like out of the ashes of the old Strasburg, were such men as Waldeyer, Recklinghausen, Leyden, Gusserow, Schmiedeberg and Fluickiger. No wonder that Strasburg has already become one of the chief centres of research in Europe!

Amongst the laboratories - the so-called instituteswhich are clustered around the Hospital of Strasburg, is the so-called Physiologisch-Chemische Institut, in which since his appointment Hoppe-Seyler has continued the work which he had begun in Berlin and in Tübingen, surrounded by pupils, many of whom-I shall merely name Baumann, Brieger, Kossel, and Thierfelder-have won for themselves honourable positions in contemporary science, and for their master the reputation of a great teacher, in the best sense of the term. Here HoppeSeyler worked until the very eve of his death. Leaving Strasburg apparently in the fulness of bealth and vigour to enjoy a few weeks of rest on his property by the shores of the Lake of Constance, Hoppe-Seyler was to be spared the misery of prolonged illness. Some sudden and unsuspected cardiac mischief brought to a standstill the life of a man of singularly great activity, intellectual as well as physical. He died on the forenoon of August Io, I895.

Arthur Gamgee.

\section{THE FUNERAL OF PASTEUR.}

$A$ MID signs of national sorrow, the funeral of Pasteur took place on Saturday last. France, more than any other nation, knows how to do honour to the memory of those who have contributed to her greatness, and by giving a national funeral, as well as taking the cost of it upon herself, she has once more shown the esteem in which she holds those who have devoted their lives to the increase of the world's knowledge and happiness. How very full was this expression may be gathered from the report of the Times correspondent at Paris. We read: "Quite a small army of infantry, marines, cavalry, artillery, and municipal guards, mounted and on foot ; deputations from all the schools and learned societies; most of those who speak and of those who govern and command in the name of France, came to render homage to the stainless glory of this Frenchman, whose genius devoted its efforts to the whole of mankind, and who deserves the gratitude of the world, not merely for the labours which he accomplished but for the new paths which he opened to science by the fresh discoveries which he made for the benefit of mankind." Shortly after ten o'clock on Saturday morning, the troops and innumerable deputations, which had assembled in and near the Pasteur Institute, marched past before the coffin containing the body of the illustrious investigator. The funeral procession was then organised. General Saussier, surrounded by his staff, and followed by the first division of infantry, preceded the hearse, and behind him came a long line of deputations, many of which had wreaths in their centre. A number of wreaths were borne on litters, and others were carried on six cars, each drawn by a pair of horses.

"Along the route from the Rue Dutot to Notre Dame," says the Times correspondent, "the compact and silent crowd respectfully uncovered their heads as the hearse passed, and the two thousand soldiers and policemen, drawn up in line to keep the way clear, had absolutely nothing to do. The pall-bearers were M. Poincaré, M. Joseph Bertrand, M. Georges Perrot, Dr. Brouardel, M. Gaston Boissier, and M. Bergeron. After marching for an hour and a half along the left bank of the Seine, the procession reached the square of Notre Dame. The aspect of the Cathedral was most impressive. The presence of President Faure, the Grand Duke Constantine, Prince Nicholas of Greece, Cardinal Richard, the whole of the Diplomatic Corps, the Ministers, the Institute of France, the office-bearers of the Senate and the Chamber of Deputies, the red-robed Judges, the members of the University faculties, in orange, red, and crimson robes, and the other distinguished persons invited-all this display of official mourning was coupled with and yet eclipsed by the profound silence, the manifest grief. The immense crowd was a rare and impressive, if not a unique spectacle."

The Royal Society was represented by Mr. W. T. Thiselton-Iyer, C.M.G., Director of the Royal Gardens, Kew. At the final funeral, which will be held in connection with the Centenary of the Institute, on the 25 th inst., several of the Officers and Fellows of the Society will be present, together with many delegates from other of our learned societies.

After the service in Notre Dame, the coffin containing Pasteur's remains was removed to a catafalque outside the Cathedral, and M. Poincaré delivered an oration before it, on behalf of the Government.

Thus does France venerate the memory of her noblest son. But France is not alone in her grief. The human race joins with her in mourning the loss of one who has done so much for humanity and science. The name of him to whom the world owes so much good is imperishable.

\section{NOTES.}

IN July of this year, a special Parliamentary Committee, of which Mr. Rhodes, the Premier, was a member, sat in Cape Town to consider the advisability of beginning a systematic geological survey of the Colony. The Committee, after hearing evidence, recommended the House of Assembly to appoint a standing Commission which should take charge of the work, and become in the first instance responsible for its being efficiently carried out. Parliament having accepted this recommendation, the warrant appointing the Commission has been duly drawn up and signed by the Governor of the Colony. The following gentlemen compose the Commission : the Hon. I. X. Merriman, M.L.A.; Dr. Gill, Astronomer Royal ; Dr. Muir, Superintendent General of Education; Mr. Charles Currey, Under-Secretary for Agriculture; and Mr. Thomas Stewart. The three first-mentioned are Trustees of the South African Museum, Cape Town, and it is intended that the geological staff shall have its headquarters in the new museum building, which is just approaching completion. In past years a great

NO. I 354 , vOL. 52 ] 